OPEN ACCESS ISSN 2527-9246 (online) ISSN 2338-445X (print)

Edited by:

IImi Usrotin Choiriyah

Reviewed by:

Tri Yuniningsih and Lely Indah

Mindarti

${ }^{*}$ Correspondence:

Evvy Silalahi

evyta21@gmail.com

Published: 01 Maret 2020

Citation:

Silalahi E and Rustanta A (2020)

Multimodality analysis of Jokowi's

Social Exchange Theory and

Political Marketing to Ma'ruf Amin's infidelity at the 2019 Presidential

Election Contestation.

JKMP (Jurnal Kebijakan dan

Manajemen Publik). 8:1.

doi: 10.21070/jkmp.v8i1.690

\section{Multimodality analysis of Jokowi's Social Exchange Theory and Political Marketing to Ma'ruf Amin's infidelity at the 2019 Presidential Election Contestation}

\author{
Evvy Silalahi*, Agustinus Rustanta
}

Sekolah Tinggi Tarakanita

In the constellation of the 2019 presidential election, there is something very interesting. Prabowo's camp quickly announced his vice-presidential candidate but Jokowi did not immediately announce his chosen vice-presidential candidate. Even until the last moment, Jokowi let the issue of the vice-presidential candidate rolling in the community. Unexpectedly, Jokowi chose a man who was never included in consideration of public. Jokowi's choice also made several names with the initials $M$ as stated himself that his chosen vice-presidential candidate was M. Surprisingly, he announced that his chosen vice-presidential candidate was Ma'ruf Amin, a senior cleric and Chairman of the MUI (Majelis Ulama Indonesia). The issue of Ma'ruf Amin's selection in this study focuses on social exchange theory from Richard Emerson and the concept of political marketing from Jennifer Lees, especially the MOP (Market Oriented Product) model with a qualitative multimodality approach. Data were analysed using a visual text analysis to dig deeper into Jokowi's non-verbal meaning by deciding to choose Ma'ruf Amin as a vice-presidential candidate. The data were photos of the nomination of the presidential and vice-presidential. The findings of this study are that the election of Ma'ruf Amin is the most appropriate and accurate choice to defeat Prabowo. By choosing Ma'ruf Amin, Jokowi won before competing against Prabowo. Ma'ruf is a symbol, means, and source of Jokowi's victory

Keywords: Multimodality, Social exchange, political marketing

\section{INTRODUCTION}

The political world is a world full of meaning. If we talk about politics, it will not be separated from the talk about power. This is in line with the opinion of Laswell (1972) in that politics is about "who gets what, when and by how", including power Budiardjo (2006).So to get power requires a variety of ways, one of which is through proper political communication to win the battle. This is what happened in Indonesia in the 2019 Presidential Election contestation. Political communication in the 2019 election was one of the real political communications. Political communication occurred from the beginning before the campaign period. One of them was the determination of Prabowo's vice-presidential candidate who was very fast while Jokowi was stalling to announce the vice-presidential candidate (jawapos.com, 2018; beritasatu.com, 2018). Both presidential candidates have their intentions in announcing their vice-presidential candi- 
dates.

As incumbent candidate, Jokowi received a lot of criticism and even attacks from the opposing party that he belonged to a group that criminalized clerics, sided with foreign henchmen, oppressing the Muslims, often even called the Party of Indonesian Communist (PKI) (detik.com, 2019) This political attack turned out to be used by Jokowi to elect a vice-presidential candidate. With these various blasphemies, Jokowi made it a sign. Apparently, Jokowi knew that the political opponents in the 2019 elections were not easy, choosing the wrong candidate of presidential representative would result in defeat (Liputan6.com, 2018). His opponent is Prabowo who has a large mass base. Various speculations of presidential candidates appear. we don't know from where the source is, some names have surfaced. But apparently, Jokowi chose someone who had never even appeared in political talks (cnnindonesia.com, 2018). Maybe Jokowi considers it like a communication theory that often relates it to profit and loss. Jokowi has counted and considered the prospective representative to be nominated. Many considerations were made to look further at what are the benefits or what are the diadvantages of having someone for the next five years.

There are even ten names that circulate from where they came from. They are Sri Mulyani, AHY, Moeldoko, Mr. Guru Bajang (former Governor of NTT), Hartarto, Muhaimin Iskandar, and Mahfud MD. The names freely roll in the public conversation into an issue (liputan6.com, 2018; cnnindonesia.com, 2018) The possibility is that Jokowi wants to see how the citizens react when the names roll on the vice-presidential nomination arena. Even the ten names conical into five names. Jokowi finally gave a clue that the name of the vice-presidential candidate is with the initial of M. suddenly occurred in the community. Some even said that Mahfud MD was predicted to be a strong candidate. There are even other initials $\mathrm{M}$ names that declare themselves candidates for vice president. But Jokowi did not choose those names. He surprisingly chose Ma'ruf Amin as a 2019-2024 vice-presidential candidate (Liputan6.com, 2018). Unpredictable decisions and public expectations had been circulating so far.

Jokowi has never said openly why he chose Ma'ruf Amin as a vice-presidential candidate. Why did he not choose one of the supporters' general secretaries? Why did he choose people outside the party who were currently serving as MUI (Majelis Ulama Indonesia) Chairman? Jokowi knows that his political opponent, namely the presidential candidate, that Prabowo who has a very large mass base despite losing the last 2014 presidential election. Jokowi needs a good political marketing concept so he must choose the right way to defeat Prabowo. Based on these facts, the scholar sees that the issue is interesting to be analyzed in depth to interpret Jokowi's choice scientifically.

Jokowi's political step through his decision to choose Ma'ruf Amin deserves scientific study. By choosing Ma'ruf, Jokowi won the political battle before the election process itself began. Jokowi has broken his assumptions and accusations. The opposing camp that always echoes the love of the ulama but instead the vice president is not an ulama (Islami.co, 2019; Liputan6.com, 2019; Republika.co.id, 2019; Jawapos.com, 2018). Jokowi's decision is at the same time an answer to the accusations he currently receives verbally and non-verbally. Therefore, the aim of this research is to examine Jokowi's political steps in winning the 2019 presidential election through a message in Ma'ruf Amin's appearance that looks consistent wearing a cap, scarf and sarong.

\section{RESEARCH METHODOLOGY}

To achieve the research objectives, researchers analyzed the 2019 presidential election phenomenon by using a visual text analysis. The multimodality method is implemented to refer to communication that involves many modes (verbal, non-verbal, etc.) such as sound, pictures, gestures and hand movements, facial expressions and clothing. Multimodality focuses on the process of creating meaning by examining various sources of meaning forming together and seeing how the combination and interaction between various modes in generating meaning as a whole (O'Halloran et al., 2011). A descriptive qualitative analysis of Jokowi's strategy is needed to win the 2019 presidential election in terms of political communication. Data obtained from news both online and in print since the determination of the presidential and vice presiden- 
tial candidates by the KPU (Komisi Pemilihan Umum) until the campaign period is over. The collected data were then analyzed with a visual text analysis data analysis. The formation of meaning in the digital world is increasingly widespread. The focus of attention shifts from oral and written to forms of visual communication. The process of creating meaning is not only done through language, but also through visual forms such as colors, typography, and so on

The basic assumptions of the Multimodality method are (1) the keyword of multimodality is the use or making of signs (sign-making) Kress (2003). The multimodality method holds that humans are basically sign makers. In this research, the writer focuses on non-verbal messages conveyed by Jokowi when cooperating with Ma'ruf Amin. Messages analyzed through appearance photos on digital media. The multimodality analysis tool used by the author is a digital text analysis knife.

\section{RESULTS AND DISCUSSION}

\section{Social Exchange Theory}

Social exchange theory is a theory that examines and considers human relationships based on profit and loss (Roloff, 2009; Stafford, 2008). Every relationship requires time and sacrifice from the people involved in it, both personal and social relations. On the other hand, Monge and Contractor (2003) argue that each person assesses and calculates the overall value of a particular relationship by reducing losses from the available benefits, so there is a value or benefit seen from a relationship. There are two values in the relationship that is seen, namely positive and negative values. A positive value if the benefits are greater than losses and vice versa. Social exchange theory even emphasizes the results that are influenced by the value of a relationship. Whether the relationship will last or end (West and Turner, 2017).

Furthermore, state in social exchange theory, the main strength of a relationship, especially interpersonal, is the satisfaction of self-interest of both. People become satisfied when they receive a fair return for their expenses. In social exchange theory, there are assumptions of human nature namely (1) humans seek profits and avoid punishment, (2) humans are rational creatures, and (3) the standards used by humans to evaluate losses and profits vary from time to time and from people to people.

The assumption of Social Exchange Theory makes the nature of relationships include interdependence and realize that life is a process. In this study using the exchange theory that was coined by Richard Emerson (1962), where Emerson's theory links the theory of exchange with power and dependence. Emerson further stated that power is the center of attention of exchange theory. In Ritzer and Douglas (2008), Emerson states there are three core theoretical assumptions important in his theory: first, people who feel competition is beneficial to them tend to act rationally as soon as competition occurs; secondly, because people end up feeling tired of competition, the benefits of competition will diminish; The three benefits that people get through social processes depend on the benefits they are able to provide in exchange, giving theories of exchange, focusing on the flow of benefits through social interaction. He began to build social exchange theory which treats the social structure as an affected variable.

Emerson defines power as "the level of potential costs that cause an actor to force other actors to "accept", whereas dependence involves "the level of potential costs that an actor receives in a relationship". Unbalanced power and dependence cause imbalances in relationships, but over time this imbalance will move towards an increasingly balanced powerdependency relationship. Power-dependency it self can emphasize positive and negative results. This implies that power can come from the ability to give gifts and punishment (Molm, 2003)

\section{Political Marketing}

Political Marketing is a marketing concept used in explaining the relationship between political products and market needs (Liliker, 2005). There are several concepts of political marketing that are often used, namely the concept of political marketing according to Bruce Newman and Jennifer Lees. In this study the researcher uses the concepts and models of political market- 
ing according to Jennifer Lees. Why did the researcher choose the concept? This is related to Jokowi's choice of Ma'ruf Amin as his running mate. Certainly, there are many considerations for a presidential candidate, especially the incumbent when selecting his running mate candidates so that they are worth selling and can win the market. There are 3 models of political marketing according to Jennifer Lees (2009):

a. Product Oriented Party (POP), which is oriented to the product, where the candidate already has a product/candidate and is trying to be chosen by the market.

b. Sales Oriented Party (SOP), which is sales oriented, which already has a product/candidate but must still be adjusted to the desires of the voters.

c. Market Oriented Part (MOP), which is market oriented, but adjusted to the market or voters' desires. MOP believes that to win the election, the party/candidate must first identify what the market wants (voters). What are the needs and desires of voters. On that basis, political products are made based on what the voters want. MOP does not pretend to change market views, instead offers what the needs and desires of the market (voters).

\section{Previous research}

During the presidential election, political communication was not only carried out during the campaign. Certain strategies are needed so that all members of the coalition or support party are solid and contribute to the winning of the candidates being promoted. Jokowi in this case has made the choice of Ma'ruf Amin as a vice-presidential candidate with no reason. One of them is to maintain the solidity of the bearers' party. In addition, the determination of the vicepresidential candidate from among the ulema has another positive impact.

If we observed, Jokowi uses a variety of strategies to gain support not only for re-voters but for new voters and even millennial voters. One way is to approach the millennial account. Jokowi is active using social media Instagram with his grandchildren, with his children. The Jokowi is interested in his new hobby; i.e. riding a motorcycle. highlighted Jokowi's political communication strategy through social media Instagram. As explained in the generation theory, the use of social media is booming. Jokowi did not miss the new habit of taking selfies with family and residents. Jokowi's new habit was also researched by Meliala \& Nurdiansyah (2019) who focused on the use of Instagram in the research. It was explained that until June 8 , 2019, Jokowi's Instagram account had posted 1,373 posts and was followed by 21 million followers. It was found that the relationship between Instagram usage and electability is very strong, 0.754 and was proven by the amount of Jokowi's electability which reached $56.8 \%$. According to Shahreza (2017), Jokowi also uses generation theory to approach prospective voters as it is often said that he is a lover of rock songs. Indonesian rock groups that he likes, for example Slank. He is also easy to take selfies with anyone. According to generation theory, the ages of young voters are included in Generation Z who were born 1999-2012. In the 2019 election they were classified as new voters with a percentage reaching $23.84 \%$ in the 2019 election (Shahreza, 2017).

Furthermore, found three strategies of political marketing ahead of the 2019 Presidential Election, namely (1) self-promotion strategy, namely by uploading photos of his success in various places in Indonesia, (2) ingratiation strategy (pleasing others) where Jokowi wanted to be perceived as individuals who are pleasant and friendly to the public or the community. The form is posting videos that bring up positive emotions and (3) exemplification strategies (role models). This strategy can be seen frequently Jokowi demonstrates his ability to interact with the public, build infrastructure, prosper the athlete, and his ability to lead the family. All of this is posted on video via Instagram. This strategy was different from when Jokowi joined the 2014 presidential election contestation. At that time, Jokowi used 5 stages of marketing communication namely product, promotion, price, place, position, and segmentation (Setiowati, 2015). Considering his formidable political opponents and the defeat of Jokowi's party in a number of large mass bases such as DKI Jakarta and North Sumatra in the Pilkada, the PDIP reminds Jokowi no to be careless in choosing a vice presidential candidate. Observing the political style and communication messages shown by Jokowi and his supporting party, the writer uses Emerson social exchange theory and the concept of political marketing that was coined by Jennifer 
Lee with the MOP model.

The coming of Ma'ruf Amin's name as a vice-presidential candidate from the Jokowi camp surprised many parties. There are names that had been nominated with the initials $\mathrm{M}$ wating to selected by Jokowi. What is the reason for Jokowi to appoint $\mathrm{KH}$ Ma'ruf Amin the MUI chairman to be his representative? In this case the author discusses in terms of social exchange theory. The theory of social exchange according to Blau (1964) is that a relation occurs because of the exchange of rewards found in the relationship between individuals. This is more deeply discussed in the exchange theory proposed by Richard where Emerson links power and dependence. Jokowi and his supporting party eventually chose Ma'ruf Amin from all names offered because of their dependence and their purpose was power. Then what is the reward for Jokowi by choosing Ma'ruf Amin? We can see that the background of Ma'ruf Amin is the MUI chairman and a scholar from the largest Islamic organization, Nahdatul Ulama, the Sarongan. From Ma'ruf's very religious appearance conveyed the implied message that Jokowi was a very Indonesian President. This can be seen from the candidate he chose.

\section{CONCLUSION}

The author concludes that Richard Emerson's (1962) social exchange theory is very relevant to use in politics until now, because it assesses the relationship of two social actors with matters relating to profit and loss. Jokowi's political communication by choosing Ma'ruf Amin was an accurate choice because Jokowi psychologically won a political contestation before he competed. The ignorance of political opponents actually becomes an opportunity for Jokowi to fulfill the public's desire for figures who are considered to be role models in accordance with Indonesian culture. By choosing Ma'ruf, the benefits have been obtained without having to work harder. Jokowi could have chosen other political actors such as Mahfud MD, but Mahfud MD does not necessarily give Jokowi a reward. Then the authors also concluded that the use of the concept of political marketing with the MOP model is still relevant in Indonesia. Jokowi's party saw how voters' behavior in Indonesia gave their political rights so that the election of Ma'ruf Amin was the answer to public needs. Ma'ruf has proven "selling points" or competitive advantage.

\section{ACKNOWLEDGMENT}

Ma'ruf's appearance with a cap and a sarong and a scarf wherever he goes, is essentially the original culture of Indonesia. By choosing Ma'ruf Amin, the base of votes for Jokowi's victory has increased considerably. This is a factor that makes Jokowi will continue to preserve his power while Ma'ruf Amin gets the position of vice president as a "gift" for himself and his party. The appearance of Ma'ruf Amin certainly broke Jokowi's political opponent's attack that Jokowi was anti-Islam. From the visual text analysis conducted by the writer through the multimodality method, the writer examines digital photographs of Jokowi and Ma'ruf Amin

From Ma'ruf's perspective, it might not have personally occurred to me to get the chance to occupy the RI-2 seat, but Ma'ruf's position as former MUI chairman and sarongan who had the first largest Muslim mass base in Indonesia became a strong exchange rate and social capital to get a high bargaining position to become the number two person in this country. The figures that reflect Indonesia and anti-West are more visible to Ma'ruf Amin than Sandiaga Uno with Prabowo Subianto. And Ma'ruf Amin's figure is a brand that is in line with the current political market in Indonesia.

\section{REFERENCES}

Blau, P. M. (1964). Exchange and Power in Social Life (New York, London, Sydney: John Wiley \& Sons, Inc).

Budiardjo, M. (2006). Dasar-Dasar Ilmu Politik (Jakarta: Gramedia Pustaka Utama)

Emerson, R. (1962). Power-dependence relations, Politica Marketing in Comparative Perspective 27.
Kress, G. (2003). Literacy in the New Media Age (London: Routledge).

Molm, L. D. (2003). Theoretical Comparisons of Forms of Exchange. Sociological Theory 21, 1-17. doi: 10.1111/ 1467-9558.00171

O'Halloran, K. L., Tan, S., Smith, B. A., and Podlasov, A. (2011). Multimodal analysis within an interactive software environment: critical discourse perspectives. Critical 
Discourse Studies 8, 109-125. doi: 10.1080/17405904.2011. 558687.

Roloff, M. (2009). Social exchange theory dalam S.W. Little John dan K.A. Foss (Ed), Encyclopedia of communication theory 2 .

Shahreza, M. (2017). Komunikator Politik Berdasarkan Teori Generasi. Journal of Communication 1. doi: 10.31000/ nyimak.vli1.273.

Stafford, L. (2008). Social exchange theories, dalam L.A. Baxter dan D.O Braithwaite (Ed), Engaging theories in interpersonal communication: Multiple perspectives (Thousand Oaks, CA: Sage).

West, R. and Turner, L. H. (2017). Introduction Communication Theory : Analysis and Application (McGraw-Hill Education).
Conflict of Interest Statement: The authors declare that the research was conducted in the absence of any commercial or financial relationships that could be construed as a potential conflict of interest.

Copyright $\odot 2020$ Silalahi and Rustanta. This is an open-access article distributed under the terms of the Creative Commons Attribution License (CC BY). The use, distribution or reproduction in other forums is permitted, provided the original author(s) and the copyright owner(s) are credited and that the original publication in this journal is cited, in accordance with accepted academic practice. No use, distribution or reproduction is permitted which does not comply with these terms. 